\title{
Mountain mahogany and cottonseed meal as supplements for grass hay
}

\author{
G. NUNEZ-HERNANDEZ, JOE D. WALLACE, JERRY L. HOLECHEK, MICHAEL L. GALYEAN, DOUG W. KING, AND ROBERT M. \\ KATTNIG
}

\begin{abstract}
Sixteen wether lambs ( $(\mathrm{sg}$ weight $34.5 \mathrm{~kg}$ ) were used to study the influence of 2 sources of supplemental protein, leaves of mountain mahogany (Cercocarpus montanus Raf.) and cottonseed meal, on $\mathbf{N}$ digestibility and balance, forage digestibility, and voluntary intake by sheep fed a low-quality grass hay. Treatments were grass hay alone (C), $C$ plus cottonseed meal, $C$ plus mountain mahogany, and $C$ plus mountain mahogany and cottonseed meal. All supplements provided $42 \mathrm{~g}$ of supplemental crude protein per head daily. Treatments were assigned to wethers within blocks according to a randomized complete block design. Supplemental $\mathbf{N}$ increased $(P<0.01) \mathrm{N}$ digestibility and balance regardless of source; however, lambs supplemented with mountain mahogany digested less $(P<0.01) \mathrm{N}$, but their $\mathbf{N}$ balance did not differ $(P>0.10)$ from those supplemented with cottonseed meal. Wethers supplemented with mountain mahogany plus cottonseed meal ate more $(P<0.05)$ organic matter $(O M)$ than the average consumed by those given either of the 2 supplements alone. Protein supplementation did not affect $(P>0.05)$ OM or fiber digestibility. Range management practices that encourage dormant season utilization of mountain mahogany by ruminants in the Southwest could reduce supplemental protein needs; such practices might include reserving mountain mahogany sites for winter use as well as greater use of mountain mahogany (and other palatable, highly nutritive shrubs) in range restoration programs in mountainous areas.
\end{abstract}

Key Words: Cercocarpus montanus, nitrogen balance, nutrient digestibility, blue grama, shrub utilization, sheep nutrition

Mountain mahogany (Cercocarpus montanus Raf.), a bushy shrub, is native to the dry, mountainous regions of western North America from Montana to southern Mexico (USDA 1948). It is typically described as being high in nutritive value for all classes of livestock and as a valuable winter browse for deer (Stubbendiek et al. 1986). Although in colder areas (e.g., Utah and further north) mountain mahogany may be deciduous, it is mostly evergreen within its southern habitat range (Gay and Dwyer 1980, Boutouba

\footnotetext{
Authors are former graduate assistant, professor, professor, professor, and graduate assistants, Dept. of Anim. and Range Sci., New Mexico State Univ., Las Cruces, 88003-0003. Nunez-Hernandez is currently research scientist, Centro de Investigaciones Forestales, APDO. Postal 20, 20660 Pabellon de Arteaga, AGS, Mexico. Galyean is resident director of the Clayton Livestock Research Center, Route 1, Box 109. Clayton. New Mexico 88415.

The authors gratefully acknowledge the clerical assistance of $\mathbf{R}$. Reynolds and statistical assistance of G.M. Southward.

Journal Article 1524 of the New Mexico Agr. Exp. Sta., Las Cruces.

Manuscript accepted 10 December 1990.
}

et al. 1990). Because of its relatively high nutritive value during winter (Cordova and Wallace 1975), utilization of mountain mahogany has the potential to reduce supplemental protein needs for grazing ruminants in many range areas of the Southwest. With some shrubs, anti-quality factors like condensed tannins may reduce their nutritive value (Holechek et al. 1989); however, a series of recent studies has indicated that mountain mahogany fed to cattle, sheep, or goats, as a part or all the shrub component in low-quality diets, failed to depress digestibility of organic nutrients and often resulted in improved $\mathrm{N}$ utilization (Arthun et al. 1988; Rafique et al. 1988; Boutouba et al. 1990; Nunez-Hernandez et al. $1989,1991)$. The purpose of our research was to compare the effect of mountain mahogany and cottonseed meal supplements (fed separately or combined) on nutrient digestibility, $\mathbf{N}$ utilization, and voluntary intake by sheep fed a low-quality grass hay.

\section{Materials and Methods}

A conventional digestion trial with 14-day adjustment and 7-day total fecal and urine collection periods was conducted in a controlled-environment facility. Sixteen fine-wool (Debouillet) yearling wethers (avg weight $34.5 \mathrm{~kg}$ ) were stratified by body weight (BW) into 4 blocks of similar average BW. Wethers were confined to individual metabolism crates. Treatments were assigned randomly to animals within blocks and consisted of grass hay alone (C), C plus cottonseed meal (80 g), C plus mountain mahogany (325 g), C plus mountain mahogany $(162.5 \mathrm{~g})$ and cottonseed meal $(40 \mathrm{~g})$. All supplements provided $42 \mathrm{~g}$ of crude protein per head daily. Protein supplementation was based on maintenance requirements for a 40-kg wether (NRC 1985). Grass hay and supplements were offered daily at 0800 ; additional hay was offered at 1900 , and water and trace mineral salt blocks were provided free choice.

Mountain mahogany leaves representing current year's annual growth were hand-harvested near Las Cruces, New Mexico, during August 1988; digestion trials were conducted during October 1988. The hay was blue grama (Bouteloua gracilis [H.B.K.] Lag. Ex. Griffiths) harvested at the Fort Stanton Experimental Ranch near Capitan, New Mexico, after dormancy in September 1988. Mountain mahogany leaves and blue grama hay were dried, and, before feeding, the hay was ground to pass a $2.54-\mathrm{cm}$ screen. Chemical composition of the hay, mountain mahogany, and cottonseed meal is shown in Table 1. 
Table 1. Chemical composition (dry matter basis) of blue grama hay, mountain mahogany and cottonseed meal.

\begin{tabular}{lccc}
\hline \hline Item & Blue grama & $\begin{array}{c}\text { Mountain } \\
\text { mahogany }\end{array}$ & $\begin{array}{c}\text { Cottonseed } \\
\text { meal }\end{array}$ \\
\hline CP & 3.4 & 12.8 & 47.3 \\
ADIN & .2 & .3 & .7 \\
NDF & 80.7 & 42.6 & 35.0 \\
ADF & 51.6 & 28.4 & 19.2 \\
ADL & 9.1 & 15.7 & 10.8 \\
CT & .3 & 15.8 & .04 \\
\hline
\end{tabular}

${ }^{\circ} \mathrm{CP}=$ Crude protein, ADIN = Acid detergent insoluble nitrogen, NDF = Neutral detergent fiber, $\mathrm{ADF}=$ Acid detergent fiber, $\mathrm{ADL}=$ Acid detergent lignin, $\mathrm{CT}=$ condensed tannins (Catechin equivalents).

From days 15 to 21 of the trial, voluntary intake was determined by recording amounts of hay and supplements offered and refused. In all cases, hay was provided in amounts sufficient to obtain $>10 \%$ orts. Total fecal and urine output were recorded daily from days 15 to 21 to determine $\mathbf{N}$ digestibility and balance, along with organic matter (OM) and fiber digestibility. Daily hay and supplement samples were taken before feeding throughout the collection period. Ort samples were retained to adjust for possible sorting. Fecal samples ( $10 \%$ of total amount) were dried partially at $50^{\circ} \mathrm{C}$ for $48 \mathrm{~h}$. Urine aliquots ( $10 \%$ of total amount) were stored frozen. Urine was acidified by adding $10 \mathrm{ml}$ of $50 \%$ ( $\mathrm{vol} / \mathrm{vol}) \mathrm{HCl}$ to each collection vessel.

Chemical analyses were performed on hay, supplement, orts, and fecal samples that had been ground to pass a 1-mm screen. Dry matter, $\mathrm{OM}$, and total $\mathrm{N}$ were determined by standard procedures (AOAC 1984). Neutral detergent fiber (NDF), acid detergent fiber (ADF), and acid detergent lignin (ADL) were determined according to nonsequential procedures of Goering and Van Soest (1970). Acid detergent insoluble $\mathbf{N}$ was determined by Kjeldahl analysis on the residue after digestion in ADF solution. Total reactive tannins were determined by the vanillin/ $\mathrm{HCl}$ procedure (Burns 1971) as modified by Price et al. (1978).

Analyses of variance were conducted using the GLM procedure of SAS (1985) for a randomized complete block design. Effects in the model included block and treatment. When the treatment $F$ test was significant $(P<0.10)$, treatment means were compared according to the following single degree of freedom linear contrasts: (1) supplement vs no supplement; (2) cottonseed meal vs mountain mahogany; and, (3) average of cottonseed meal and mountain mahogany vs the combined supplement.

\section{Results and Discussion}

Soluble phenolic (PHE) and condensed tannin (CT) contents of mountain mahogany apparently undergo considerable increase with advancing maturity, although $\mathrm{N}$ content appears to change very little. Mountain mahogany leaves collected in early May (Nunez-Hernandez et al. 1989) contained $64.7 \mathrm{mg} / \mathrm{g}$ PHE and $7.4 \% \mathrm{CT}$ while leaves harvested from the same area in August (although not in the same year; Boutouba et al. 1990) contained $124.4 \mathrm{mg} / \mathrm{g}$ PHE and $15.8 \% \mathrm{CT}$. The $\mathrm{N}$ contents for mountain mahogany leaves reported for the above studies were 2.0 and $1.9 \%$, respectively. The mountain mahogany leaves fed in the present study (Table 1) were a part of the same harvest, and had the same level of CT, as those used in the goat studies by Boutouba et al. (1990). The $\mathrm{N}$ content of mountain mahogany leaves was slightly greater in our study than in those fed by Boutouba et al. ( $2.0 \mathrm{vs}$ $1.9 \%)$. Sorting of diet ingredients by the lambs was not evident in our study.

Cordova and Wallace (1975), in a study of seasonal trends of chemical composition of several forbs and shrubs (including mountain mahogany), noted that all shrub species retained more $\mathbf{N}$ and phosphorus with advancing maturity than did forbs. Phenolics and CT were not determined in the latter study.

In a study involving several shrubs common to western rangelands, Nunez-Hernandez et al. (1989) classed gray oak (Quercus grisea Liebm; $79.0 \mathrm{mg} / \mathrm{g}$ PHE) and big sagebrush (Artemisia tridentata Nutt. spp. tridentata; $61.0 \mathrm{mg} / \mathrm{g}$ PHE) along with mountain mahogany as high-phenolic shrubs. Gray oak and big sagebrush contained 6.9 and $3.4 \% \mathrm{CT}$, respectively (compared with $7.4 \%$ for mountain mahogany). In the same study, low phenolic species included common winterfat (Ceratoides lanata [Pursh.], J.T. Howell; $13.0 \mathrm{mg} / \mathrm{g}$ PHE) and fourwing saltbush (Atriplex canescens [Pursh.], Nutt.;23.3 mg/g PHE), which had CT levels of .7 and $.1 \%$, respectively. Studies reported by Boutouba et al. (1990), in which goats were fed low-quality forage diets containing up to $60 \%$ mountain mahogany or fourwing saltbush, indicated no evidence of toxicosis. This finding agrees with Nastis and Malechek (1981), who found no toxicosis in goats fed diets containing as much as $80 \%$ Gambel oak (Quercus gambelii Nutt.). Although drying may alter certain chemical properties of phenolic/tannin compounds, Robbins et al. (1987) reported that drying has only minor influences on solubility and subsequent protein utilization of these compounds by ruminants.

In the present study, lambs receiving supplemental $\mathrm{N}$, regardless of source, consumed more $\mathbf{N}$, had greater fecal and urinary $\mathbf{N}$ losses, improved $\mathrm{N}$ balance, and greater apparent $\mathrm{N}$ digestibility compared with unsupplemented control lambs (all differences $P<0.01$; Table 2). Nitrogen supplementation for sheep fed lowquality forage diets commonly results in improved $\mathbf{N}$ utilization (Leibholz and Kellaway 1984, Caton et al. 1988). Feeding lambs the combined cottonseed meal/mountain mahogany supplement

Table 2. Influence of cottonseed meal (CSM) and(or) mountain mahogany (MM) supplements on nitrogen (N) digestibility and balance in lambs fed blue grama hay.

\begin{tabular}{|c|c|c|c|c|c|c|c|c|}
\hline \multirow[b]{2}{*}{ Item } & \multicolumn{4}{|c|}{ Supplement } & \multirow[b]{2}{*}{$S E^{\mathrm{a}}$} & \multicolumn{3}{|c|}{ Contrasts $^{b}$} \\
\hline & No supplement & $\mathrm{CSM}$ & MM & $\mathrm{CSM}+\mathrm{MM}$ & & 1 & 2 & 3 \\
\hline $\mathrm{N}$ intake, $\mathrm{g} / \mathrm{d}$ & 4.0 & 8.0 & 7.2 & 9.8 & .39 & ** & NS & ** \\
\hline Fecal N, g/d & 3.7 & 4.1 & 4.6 & 5.2 & .09 & ** & NS & NS \\
\hline Urinary $N, g / d$ & 2.5 & 4.0 & 3.3 & 4.5 & .37 & ** & NS & NS \\
\hline $\mathrm{N}$ balance, $\mathrm{g} / \mathrm{d}$ & -2.2 & -0.1 & -0.7 & 0.1 & .35 & $* *$ & NS & NS \\
\hline $\mathrm{N}$ digestibility, \% & 9.5 & 48.4 & 35.0 & 46.5 & .99 & $* *$ & $* *$ & $\dagger$ \\
\hline
\end{tabular}

a Standard error of the mean, $n=4$.

Contrasts: 1) Suppl. vs. no suppl.

2) $\mathrm{CSM}$ vs $\mathrm{MM}$

$\dagger P<0.10$

3) Avg. of CSM and MM suppl. vs. CSM + MM

NS $=$ nonsignificant 
Table 3. Influence of cottonseed meal (CSM) and(or) mountain mahogany (MM) supplements on intake and digestibility of blue grama hay by lambs.

\begin{tabular}{|c|c|c|c|c|c|c|c|c|}
\hline \multirow[b]{2}{*}{ Item $^{2}$} & \multicolumn{4}{|c|}{ Supplement } & \multirow[b]{2}{*}{$\mathbf{S E}^{\mathrm{c}}$} & \multicolumn{3}{|c|}{ Contrasts $^{d}$} \\
\hline & No supplement & CSM & MM & $\mathrm{CSM}+\mathrm{MM}$ & & 1 & 2 & 3 \\
\hline $\begin{array}{l}\text { OM intake } \text { b }^{\mathrm{b}}, \mathrm{g} / \mathrm{kg} \mathrm{BW} \\
\text { OM digestibility, \% } \\
\text { NDF digestibility, } \% \\
\text { ADF digestibility, } \%\end{array}$ & $\begin{array}{l}22.1 \\
49.8 \\
49.0 \\
49.4\end{array}$ & $\begin{array}{l}19.8 \\
50.5 \\
51.4 \\
49.2\end{array}$ & $\begin{array}{l}22.2 \\
52.6 \\
49.2 \\
45.6\end{array}$ & $\begin{array}{l}24.8 \\
50.8 \\
49.1 \\
46.2\end{array}$ & $\begin{array}{l}0.65 \\
1.43 \\
1.74 \\
2.20\end{array}$ & $\begin{array}{l}\text { NS } \\
\text { NS } \\
\text { NS } \\
\text { NS }\end{array}$ & $\begin{array}{l}\text { NS } \\
\text { NS } \\
\text { NS } \\
\text { NS }\end{array}$ & $\begin{array}{l}* \\
\text { NS } \\
\text { NS } \\
\text { NS }\end{array}$ \\
\hline
\end{tabular}

${ }^{\circ} \mathrm{OM}=$ Organic matter, $\mathrm{BW}=$ body weight; NDF = neutral detergent fiber; $\mathrm{ADF}=$ acid detergent fiber

${ }^{b} O M$ intake included hay plus supplement because orts often contained inseparable amounts of diet ingredients.

'Standard error of the mean, $n=4$.

${ }^{d}$ Contrasts: 1) Suppl. vs. no suppl.

2) CSM vs MM

NS = nonsignificant

resulted in a greater $(P<0.01) \mathrm{N}$ intake and somewhat greater $(P<0.10)$ apparent $\mathrm{N}$ digestibility compared with average values found for lambs given either supplemental $\mathrm{N}$ source alone (Table 2). Lambs fed the combined supplement were in a slight positive $\mathbf{N}$ balance, whereas those fed other treatments were in a negative $\mathrm{N}$ balance.

Wether lambs supplemented with mountain mahogany had lower $(P<0.01)$ apparent $\mathrm{N}$ digestibility, but a similar $(P>0.10) \mathrm{N}$ balance, to those given cottonseed meal (Table 2). These differences are explained, in part, by the tendency $(P>0.10)$ for greater fecal $\mathbf{N}$ losses and lower urinary $\mathbf{N}$ losses in lambs supplemented with mountain mahogany vs those receiving cottonseed meal. Nitrogen balance accounts for both fecal and urinary losses while $\mathrm{N}$ digestibility considers only fecal $\mathbf{N}$ losses; thus, $\mathrm{N}$ balance represents a more meaningful index of protein utilization. Orskov (1982) described protein evaluation systems based on apparent digestibility as totally ineffective for ruminants and, as pointed out by Merchen (1988), apparent digestibility values do not reflect the nature of absorbed end-products of digestion, or the amount of energy lost during the digestive process. Nunez-Hernandez et al. $(1989,1991)$, working with sheep and(or) goats, found that feeding shrubs high in CT, increased fecal $\mathrm{N}$ but reduced urinary excretion, thereby having only negligible effects on $\mathrm{N}$ balance.

The CT in mountain mahogany may bind dietary protein and reduce ruminal proteolysis. Barry and Reid (1984) concluded that CT react with proteins, forming an insoluble complex at normal ruminal pH; albeit, tannin-protein bonds can be hydrolyzed at the $\mathrm{pH}$ of the abomasum and intestines. Nunez-Hernandez et al. (1991) reported that treating mountain mahogany leaves with polyethylene glycol to bind $\mathrm{CT}$ increased ruminal ammonia- $\mathrm{N}$ and serum urea- $\mathrm{N}$ concentrations in sheep fed low-quality forage diets-findings that were interpreted as indirect evidence that CT limited ruminal proteolysis. Similar findings also were reported by Waghorn et al. (1987) in a study with sheep fed Lotus corniculatus. In our study, $C T$ in mountain mahogany presumably caused a shift in site of $\mathbf{N}$ digestion through reduction in ruminal $\mathbf{N}$ digestion. Nunez-Hernandez et al. (1991) associated low urinary-N with reduced ruminal proteolysis and more efficient use of digested $\mathrm{N}$ by sheep and goats fed diets containing mountain mahogany. Waghorn et al. (1987) reported that CT were responsible for a reduction in ruminal proteolysis and an increase in the flux of essential amino acids through the abomasum in sheep fed Lotus corniculatus L. Barry et al. (1986) found that increasing dietary CT concentrations caused an increase in duodenal $\mathrm{N}$ flow in sheep. In our study, CT in mountain mahogany may have increased post-ruminal $\mathrm{N}$ absorption by reducing ruminal proteolysis, but the extent to which protein-tannin complexes were hydrolyzed and amino acids absorbed is unknown.

Organic matter intake by lambs fed the combined cottonseed meal/mountain mahogany supplement $(24.8 \mathrm{~g} / \mathrm{kg} \mathrm{BW})$ was greater
$(P<0.05)$ than the average $O M$ intake $(21.0 \mathrm{~g} / \mathrm{kg}$ BW) observed for lambs given either supplement alone (Table 3). Protein supplementation often results in increased forage intake by sheep fed lowquality diets, (Krysl et al. 1987, Caton et al. 1988); however, the mode of action has not been defined clearly. As pointed out by Grovum (1988), the mechanism that governs intake by ruminants is extremely complex and may include as many as 5 major longterm control factors (e.g., $\mathrm{N}$ status) and 4 short-term control factors (e.g., distension of the reticulum). The review by Baile and McLaughlin (1987) on the role of the central nervous system and certain neuropeptides in the control of feed intake in ruminants further emphasizes the complexity.

In several studies, increased passage rate has been observed along with increased voluntary intake when cattle fed low-quality diets were supplemented with protein (McCollum and Galyean 1985, Guthrie and Wagner 1988). Complementary effects between cottonseed meal and mountain mahogany may have occurred in our experiment. Combining proteins from the 2 sources may alter site of digestion and increase protein absorption. A partial shift in site of digestion from the rumen to the lower tract would alter end-products of digestion and could improve efficiency of nutrient utilization. Moreover, an increased protein supply to the small intestine often has a stimulatory effect on food intake by ruminants (Brake et al. 1989), although the mode of action for this response has not been elucidated (Owens and Zinn 1988).

Cottonseed meal supplementation increased voluntary intake by sheep fed low-quality prairie hay (Krysl et al. 1987); however, in the present study, OM intake by lambs supplemented with cottonseed meal was numerically less than that noted for lambs in all other treatments (Table 3); reasons for this response are unclear. Coppock et al. (1987), working with dairy cattle, found that DM intake was sharply depressed by cottonseed meal supplementation because of gossypol content, although a similar effect of gossypol in the present experiment is unlikely because of the limited amount of cottonseed meal fed.

Protein supplementation did not affect $(P>0.05) \mathrm{OM}, \mathrm{NDF}$, or ADF digestibility. Increased digestibility of these dietary components has been observed with $\mathbf{N}$ supplementation in some cases (Caton et al. 1988, Guthrie and Wagner 1988), but not others (Judkins et al. 1987, Rafique et al. 1988). Several shrubs, including mountain mahogany, had influences similar to alfalfa on digestibility of grass hay diets by goats and sheep (Rafique et al. 1988, Nunez-Hernandez et al. 1989). Although CT can reduce in vitro digestibility of forages (Chiquette et al. 1988), Nunez-Hernandez et al. (1991) reported that reduced ruminal ammonia attributed to CT did not influence in situ rate of NDF disappearance, potential extent of NDF digestion or in vivo OM digestibility by sheep fed low-quality diets containing mountain mahogany.

Data from our study are interpreted to suggest that supplementation with mountain mahogany and(or) cottonseed meal increased 
$\mathbf{N}$ digestibility and balance by lambs compared with unsupplemented controls fed a low-quality grass hay. Protein supplementation did not affect OM, NDF, or ADF digestibility. The CT in mountain mahogany apparently caused a shift in the site of $\mathrm{N}$ digestion, but did not affect $\mathrm{N}$ balance of the lambs. Complementary effects of cottonseed meal and mountain mahogany stimulated greater $\mathrm{OM}$ intake, presumably through altered site of $\mathrm{N}$ digestion and greater intestinal $\mathbf{N}$ absorption. Range management practices that encourage dormant season utilization of mountain mahogany by ruminants on Southwestern mountainous ranges could reduce supplemental protein needs. Such practices might include reserving mountain mahogany sites for winter use as well as greater use of mountain mahogany and other similar, highly nutritive shrubs in range restoration programs on mountainous areas. Provision of conventional protein supplements (e.g., protein blocks) in strategic range areas might encourage consumption of combined supplements (i.e., conventional plus that from palatable shrubs in the area) to produce a complementary effect such as that noted with cottonseed meal and mountain mahogany in our study.

\section{Literature Cited}

AOAC. 1984. Official methods of analyses (14th Ed.). Assoc. Official Analyt. Chem. Washington, D.C.

Arthun, D., S. Rafique, J.L. Holechek, J.D. Wallace, and M.L. Galyean. 1988. Effects of forb and shrub diets on ruminant nitrogen balance. II. Cattle studies. Proc. West. Sec. Amer. Soc. Anim. Sci. 39:204-207.

Baile, C.A., and C.L. McLaughlin. 1987. Mechanisms controlling feed intake in ruminants: a review. J. Anim. Sci. 64:915-922.

Barry, T.N., and C.S.W. Reid. 1984. Nutritional effects attributable to condensed tannins, Cyanogenic glucosides and estrogenic compounds in New Zealand forages. p. 251-259. In: R.F. Barnes, P.R. Ball, R.W. Brougham, G.C. Marten, and D.J. Minson (Ed.). Forage legumes for energy-efficient animal production. Proc. Trilateral Workshop. USDAARS. Palmerston, New Zealand.

Barry, T.N., T.R. Maniey, and S.J. Duncan. 1986. The role of condensed tannins in the nutritional value of Lotus pendunculatus for sheep. 4. Sites of carbohydrate and protein digestion as influenced by dietary reactive tannin concentration. Brit. J. Nutr. 55:123-137.

Boutouba, A., J.L. Holechek, M.L. Galyean, G. Nunez-Hernandez, J.D. Wallace, and M. Cardenas. 1990. Influence of two native shrubs on goat nutritional status. J. Range Manage. 43:530-534.

Brake, A.C., A.L. Goetsch, L.A. Forster, Jr., and K.M. Landis. 1989. Feed intake, digestion and digesta characteristics of cattle fed bermudagrass or orchardgrass alone or with ground barley or corn. J. Anim. Sci. 67:3425-3436.

Burns, R.E. 1971. Method for estimation of tannin in grain sorghum. Agron. J. 63:511-512.

Caton, J.S., W.C. Hoefler, M.L. Galyean, and M.A. Funk. 1988. Influence of cottonseed meal supplementation and cecal antibiotic infusion in lambs fed low-quality forage. I. Intake, digestibility, nitrogen balance and ruminal and cecal digesta kinetics. J. Anim. Sci. 66:2245-2252.

Chiquette, J., K.J. Chong, J.W. Costerton, and L.P. Milligan. 1988. Effect of tannins on the digestibility of two 150 synthetic strains of birdsfood trefoil (Lotus corniculatus L.) using in vitro and in sacco techniques. Can. J. Anim. Sci. 68:751-760.

Coppock, C.E., J.K. Lanham, and J.I. Horner. 1987. A review of the nutritive value and utilization of whole cottonseed, cottonseed meal and associated by-products by dairy cattle. Anim. Feed Sci. and Technol. 18:89-129.

Cordova, F.J., and J.D. Wallace. 1975. Nutritive value of some browse and forb species. Proc. West. Sec. Amer. Soc. Anim. Sci. 26:160-162.

Gay, C.W., and D.D. Dwyer. 1980. New Mexico range plants. Coop. Ext. Circ. 374. New Mexico State Univ., Las Cruces.
Goering, H.K., and P.J. Van Soest. 1970. Forage fiber analyses (apparatus, reagents, procedures and some applications). USDA-ARS Handbook No. 379.

Grovum, W.L. 1988. Appetite, palatability and control of feed intake. p. 202-216. In: Church, D.C. (ed.), The ruminant animal: digestive physiology and nutrition. Prentice Hall, Englewood Cliffs, N.J.

Guthrie, M.J., and D.G. Wagner. 1988. Influence of protein or grain supplementation and increasing levels of soybean meal or intake, utilization and passage rate of prairie hay in beef steers and heifers. J. Anim. Sci. 66:1529-1537.

Holechek, J.L., R.D. Pieper, and C.H. Herbel. 1989. Range management principles and practices. Prentice-Hall Pub. Co., Englewood Cliffs, N.J..

Judkins, M.B., J.D. Wallace, M.L. Galyean, L.J. Krysl, and E.E. Parker. 1987. Passage rates, rumen fermentation, and weight change in protein supplemented grazing cattle. J. Range Manage. 40:100-104.

Krysl, L.J., M.E. Branine, M.L. Galyean, R.E. Estell, and W.C. Hoefler. 1987. Influence of cottonseed meal supplementation on voluntary intake, ruminal and cecal fermentation, digesta kinetics and serum insulin and growth hormone in mature ewes fed prairie hay. J. Anim. Sci. 64:1178-1188.

Leibholz, J., and R.C. Kellaway. 1984. The utilization of low-quality roughages. I. the role of nitrogen and energy supplements. Australian Meat Res. Comm. Rev. 48.

McCollum, F.T., and M.L. Galyean. 1985. Influence of cottonseed meal on voluntary intake, rumen fermentation and rate of passage of prairie hay in beef steers. J. Anim. Sci. 60:570-577.

Merchen, N.R. 1988. Digestion, absorption and excretion in ruminants. p. 172-199. In: Church, D.C. (ed.), The ruminant animal: digestive physiology and nutrition. Prentice Hall, Englewood Cliffs, N.J.

Nastis, A.J., and J.C. Malechek. 1981. Digestion and utilization of nutrients in oak browse by goats. J. Anim. Sci. 53:283-289.

NRC. 1985. Nutrient requirements of sheep. (6th Rev. Ed.). National Academy Press. Washington, D.C.

Nunez-Hernandez, G., J.L. Holechek, J.D. Wallace, M.I. Galyean, A. Tembo, R. Valdez, and M. Cardenas. 1989. Influence of native shrubs on nutritional status of goats: nitrogen retention. J. Range Manage. 42:228-232.

Nunez-Hernandez, G., J.D. Wallace, J.L. Holechek, M.L. Galyean, and M. Cardenas. 1991. Condensed tannins and nutrient utilization by lambs and goats fed low-quality diets. J. Anim. Sci. 69:1167-1177.

Orskov, E.R. 1982. Protein nutrition in ruminants. Academic Press, New York.

Owens, F.N., and R. Zinn. 1988. Protein metabolism in ruminant animals. p. 227-249. In: Church, D.C. (ed.), The ruminant animal: digestive physiology and nutrition. Prentice Hall, Englewood Cliffs, N.J.

Price, M.L., S. Van Scoyoc, and L.G. Butler. 1978. A critical evaluation of the vanillin reaction as an assay for tannin in sorghum grain. J. Agr. Food Chem. 26:1214-1218.

Rafique, S., D.P. Arthun, M.L. Galyean, J.L. Holechek, and J.D. Wallace. 1988. Effects of forb and shrub diets on ruminant nitrogen balance. I. Sheep studies. Proc. West. Sec. Amer. Soc. Anim. Sci. 39:200-203.

Robbins, C.T., T.A. Hanley, A.E. Hagerman, O. Hjelford, D.L. Baker, C.C. Schwartz, and W.W. Mantz. 1987. Role of tannins in defending plants against ruminants: Reduction in protein availability. Ecology 68:98-107.

SAS. 1985. SAS User's Guide: Statistics, Version 5 ed. SAS Institute, Inc., Cary, N.C.

Stubbendiek, J., Stephan L. Hatch, and Kathie J. Hirsch. 1986. North American range plants. Univ. Nebraska Press, Lincoln.

USDA. 1948. Woody plants seed manual. U.S. Forest Serv. USDA Misc. Pub. 654, U.S. Gov. Printing Office, Washington, D.C.

Waghorn, G.C., M.J. Ulyatt, A. John, and M.T. Fisher. 1987. The effect of condensed tannins on the site of digestion of amino acids and other nutrients in sheep fed on Lotus corniculatus. Brit. J. Nutr. 57:115-126. 